Military Technical College

Kobry El-Kobbah, Cairo, Egypt

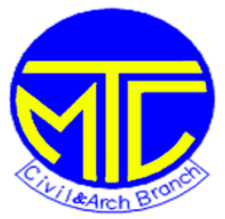

$12^{\text {th }}$ International Conference on Civil and Architecture Engineering

\section{ICCAE-12-2018}

\title{
Tsunami deposits and hazard along north coast of Egypt correlate with historical earthquake records of eastern Mediterranean
}

Asem Salama (1,2), Mustapha Meghraoui (1), Mohamed El Gabry (2), Said Maouche (3), Hesham Hussein (2), and Ibrahim Korrat (4)

(1) Institut de Physique du Globe, CNRS - UMR7516, Strasbourg, France (a.salama@unistra.fr), (2) NRIAG, 11421 Helwan, Egypt, (3) CRAAG, Dept. of Geophysics, Bouzareah-Algiers, Algeria, (4) Mansoura University, Mansoura, Egypt

Abstract
Paleotsunami deposits and tsunami
scenarios are investigated along the north coast of Egypt in the framework of the National Research Institute of Geophysics and Astronomy (NRIAG) and EC-Funded ASTARTE European tsunami and the French-Egyptian IMHOTEP projects. The study area located west of Alexandria is selected according to historical earthquakes and related inundation events as recorded in the archives. The two selected sites at Kefr Saber 32-km west of Marsa Matruh city and $\sim 10 \mathrm{~km}$ northwest of the $\mathrm{El}$ Alamein village are inner Laguna protected by 2 to 20-m-high dunes parallel to the shoreline. The two selected sites were chosen according to geomorphological and geological aspects. Five trenches and 12 cores were dug in two selected sites Kefr Saber and EL Alamein. X-ray scanning, magnetic susceptibility, grain size analysis, sampling and macrofossil detections, XRD analysis, total organic and inorganic matter measurements and carbon dating were carried out to identify the paleotsunami signatures. The high energy white sandy layer with rich in reworked fossils at Kafr Saber are correlated with 21 July 365 in Kafr Saber, while the four characteristic high energy sedimentary layers at the El Alamein site are correlated with the historical tsunami events of $1600 \mathrm{BC}, 21$ July 365, 8 August 1303, 24 June 1870.

\section{Introduction}

Since the beginning of the 20th century, many efforts have been done towards the establishment of a reliable catalogue of historical seismicity based on the retrieval and assessment of original sources of information (e.g. Poirier \& Taher 1980, Maamoun (1984), Soloviev et al. 
2000, Ambraseys (2005, 2009), Guidoboni and Ebel, 2009). Egypt has a welldocumented history of earthquakes and catastrophes preserved in a variety of sources due to its long history of civilization and important geographic position (Fig 1). The preserved original documents and archives are considered as the principle sources of macroseismic data for historical earthquakes and tsunamis.
Among these historical earthquakes and tsunamis (Fig.1), the tsunamis of 21 July 365,8 August 1303 were having a great damage to the city of Alexandria as well as the Mediterranean coast of Greece, Sicily, Libya, Cyprus, Syria, Lebanon and Palestine. These two events were the most probably triggered by major earthquakes in the Hellenic subduction zone (Papadopoulos et al., 2014).

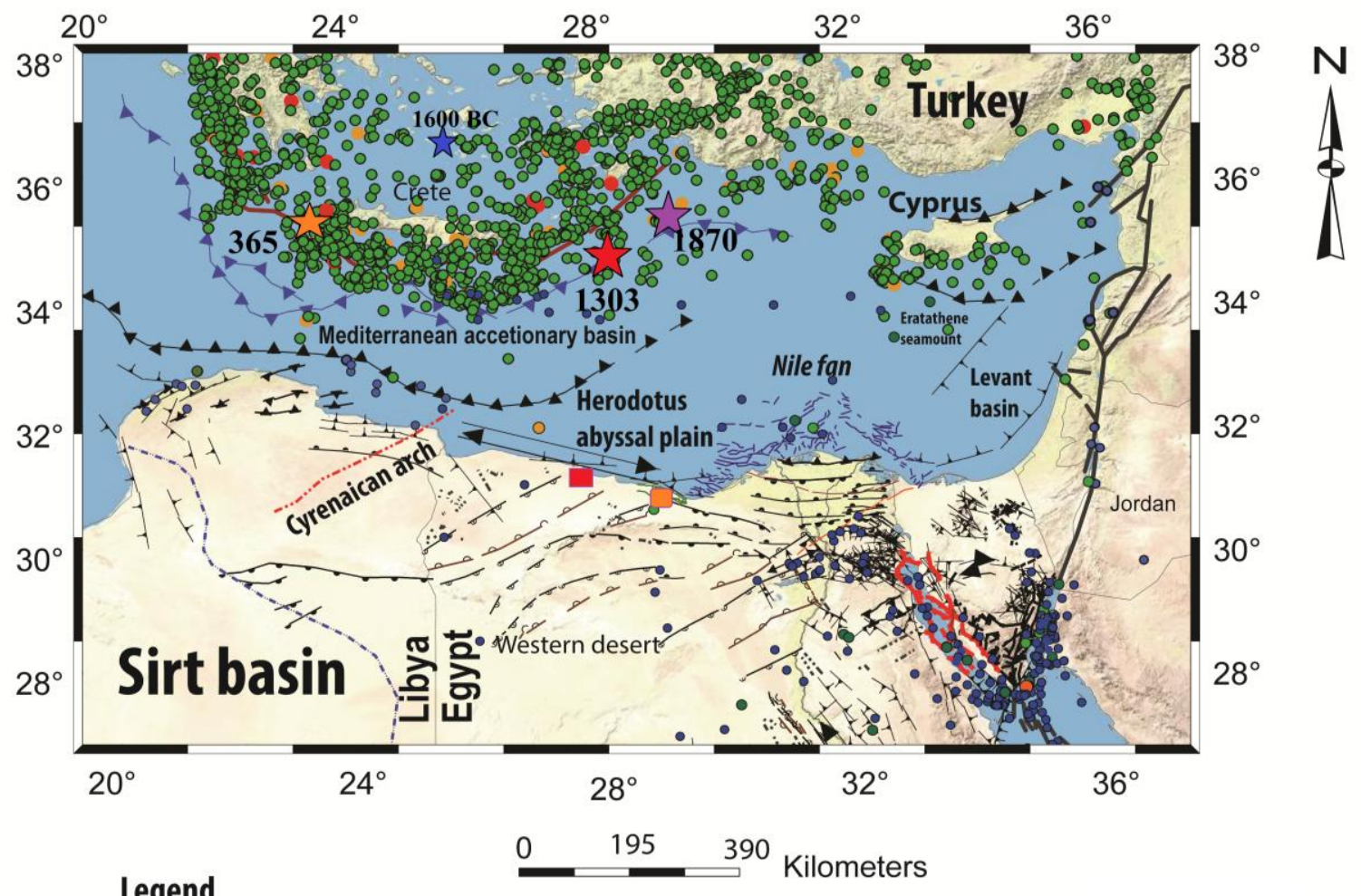

\section{Legend}

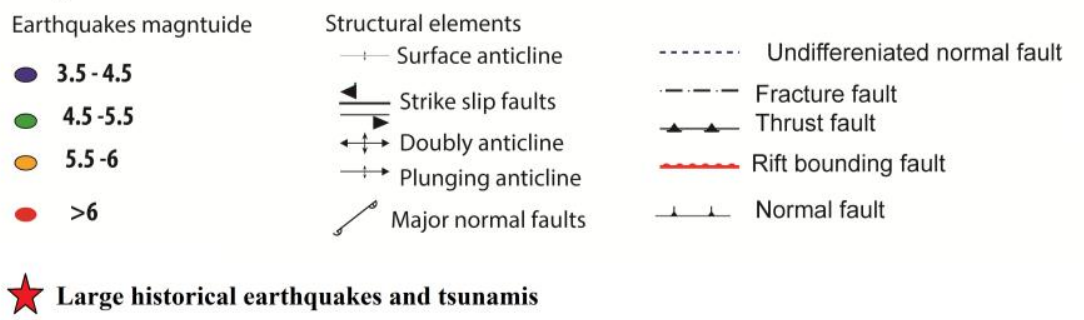

Paleotsunami investigated sites

El Alamein

Kafr Saber

Large historical earthquakes and tsunamis

Fig.1 Seismic activity and tectonic mapbased on geological map of Libya, 1985 geological map of Egypt (EMRA 2008),Bathworth 2008, and seismicity data for north Egypt of NRIAG bulletin 
from 1997-2016 and the seismicity data of the Eastern Mediterranean from IRIS bulletin http://ds.iris.edu/ds/nodes/dmc/data/types/events/ )

We are aiming to investigate the paleotsunami deposits and their correlation with the historical tsunami catalogue of the Eastern Mediterranean. The investigation is presented through trenching and coring along the Mediterranean coast of Egypt and examines the geological evidence using geochemical analysis, magnetic susceptibility and radiocarbon dating to identify the tsunamis records.

sizes of the trenches are $\sim 2 \times 1$ meter with $\sim 1.5$-m-depth. The maximum depth of cores is $\sim 2.6 \mathrm{~m}$ and underwent $\mathrm{X}$-Ray imaging sent to the laboratory of the National Institute of Geophysics and Astronomy (NRIAG, Cairo) for sampling and further measurements.

The core tubes were split lengthwise, photographed using both normal and ultraviolet lightning, X-ray scanning immediately after opening, detail description of textures and sedimentary structures, magnetic susceptibility measurements and finally collecting samples for radiocarbon dating, chemical and organic matter analyses.

Magnetic susceptibility was measured for cores at NRIAG lab then corrected against air by using Bartington compatible software. 120 samples were collected from cores then analyzed of grain size analysis; X-ray diffraction using Philips PW 1730. Total organic and inorganic measurements were carried out at the laboratory of Metallurgical Research Center

\section{Methods}

Two sites are chosen with $160 \mathrm{~km}$ apart have met the selection criteria for site investigation (Figs. 1): 1) Kafr Saber located at $\sim 32 \mathrm{~km}$ west of Marsa-Matruh city, and 2) El Alamein site at $\sim 10 \mathrm{~km}$ northwest of $\mathrm{El}$ Alamein village. Five trenches and four cores were carried out at Kafr Saber, and five trenches and 12 cores were carried out at the Alamein site. The of Tbin, Egypt. Statistics of the grain-size distribution were calculated using Folk equations (1968) to calculate mean size and sorting of the sediments along the cores.

\section{Results}

The geomorphological landforms along the northern Egyptian coast are characterized by sand dunes, accumulation of large boulders, lagoons. The large accumulation of boulders extends along the Egyptian coast particularly in Ras EL Hekma and Kafr Saber which have boulders rich in Dendrompa species.

The cores and trenches in both the Kafr Saber and Alamein sites were dug during three periods of field works in order to identify the tsunami deposits according their interpreted sedimentary tsunami signatures The stratigraphic log of the trenches in Kafr Saber mainly show one tsunami layer of mixed sand and gravel, and broken shells at a depth of $\sim 35 \mathrm{~cm}$ (see the 
composite section in Fig.2 with corresponding dating samples).

The cores in El Alamein show four main layers, characterized by fine and coarse sand mixed with broken shell fragments that indicate the occurrence of high energy sedimentary deposits in the coastal lagoon environment (see the composite section in Fig.3). A remarkable observation is the similarity of the white layers of sand with broken shells observed in trenches and cores at both sites $\sim 200 \mathrm{~km}$ apart. We interpret these as tsunami deposits due to their sedimentary signatures observed from our analysis and measurements.

compared with the 21 July 365 tsunami (simulated tsunami event $\mathrm{X}$ ) as shown in Fig. 2.

It appears that the tsunami deposits of the $365 \mathrm{AD}$ tsunamigenic earthquake have a larger thickness at Kafr Saber site than at the El Alamein site. However, the opposite trend is seen for the $1303 \mathrm{AD}$ and 1870 AD sedimentary layers which are thicker at the El Alamein site. These observations can be justified by the proximity of the tsunamigenic source in western Crete and 365 AD earthquake with respect to the Kafr Saber site, and the proximity of the $1303 \mathrm{AD}$ and $1870 \mathrm{AD}$ seismic sources in the east Hellenic Arc with

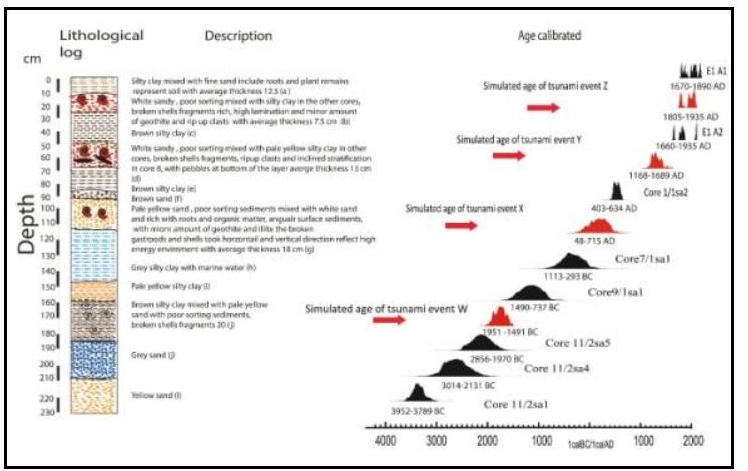

The chronology of sediments in cores in El Alamein was constructed with the Bayesian simulation provides the dating of the four tsunami deposits using the Oxcal software Bronk-Ramsay (2001). The tsunami layers are comparable with the four historical events: simulated tsunami event (W, 1600 BC (Santorini tsunami?) ; simulated tsunami event (X, 21 July 365); (simulated tsunami event Y, 8 August 1303) ; (simulated tsunami event Z, 24 June 1870), as shown from the probability density function (PDF) of the Oxcal program as shown in Fig. 3. One recognized stratigraphic tsunami layer at Kafr Saber regards to the El Alamein paleotsunami site.

Fig.2 Composite section in Kefr Saber

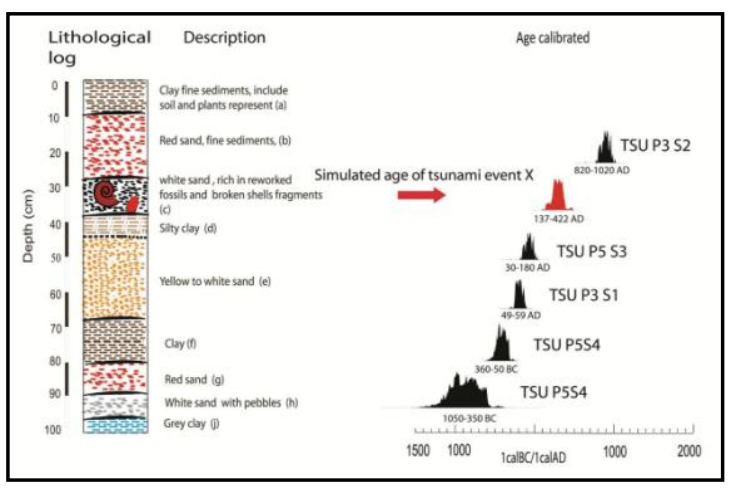

Fig.3 Composite section in ElAlamein

\section{Acknowledgment}

We thank the EC-Funded ASTARTE project (Assessment, Strategy and Risk Reduction for Tsunamis in Europe, The French-Egyptian IMHOTEP project and French Cultural Center in Cairo. We are 
grateful to Prof. Hatem Odah, Dr. Assia Harbi, Adel Samy, Hany Hassen, Mohamed Maklad, Mohamed Sayed and NRIAG administration and staff for their keen efforts and help during the development of this work. We are grateful to the French Centre d'études Alexandrines for providing their drilling equipment. Special thanks to Egyptian Armed Forces for issuing permissions and their support during field work.

\section{References}

Ambraseys, N.N., Melville, C.P. and Adams, R.D., (2005). The seismicity of Egypt, Arabia and the Red Sea: a historical review. Cambridge University Press.pp.181.

Ambraseys, N., (2009). Earthquakes in the Mediterranean and Middle East: A Multidisciplinary Study of Seismicity up to 1900 , pp. 947 , Cambridge University Press, ISBN: 9780521872928.

Bronk Ramsey, C., (2001). Development of the radiocarbon calibration program: Radiocarbon, Vol. 43, no. 2, p. 355363.

Bosworth, W. (2008). North AfricaMediterranean present-day stress field transition and implications for fractured reservoir production in the eastern Libya basins, Geol. East Libya Vol.4, p.123-138.

Egyptian National seismic network (ENSN) Bulletin (1998-2004). Earthquakes in and around Egypt. National
Research Institute of Astronomy and Geophysics(NRIAG), Egypt

EMRA Egyptian Mineral Resource map (2008), unpublished geological, personal contact with Mohamed M. Masnour (Director of regional geology department in Egyptian mineral resources authority).

Folk, R.L.,(1968), Petrology of sedimentary rocks, in Austin, Texas (HemphilPs Book Store). Journal of Sedimentary Research, Vol. 27(1), pp. 182.

Geological map of Libya (1985). http://www.sepmstrata.org/page.aspx ?pageid $=143$.

Guidoboni, E. and J. E. E. (2009) Guidoboni, E. and J. E. Ebel. Cambridge University Press.pp.584 doi: 978-0-521-83795-8.

Maamoun, M., Megahed, A. and Allam, A., (1984). Seismicity of Egypt: NRIAG Bull., IV (B), p. 109-160.

Papadopoulos GA, Gra`cia E, Urgeles R, Sallares V., (2014). Historical and pre-historical tsunamis in the Mediterranean and its connected seas: geological signatures, generation mechanisms and coastal impacts. Mar Geol, Vol. 354, p. 81109.

Poirier, J. P. \& Taher, M.A., (1980). Historical seismicity in the near and middle east, North Africa, and Spain from Arabic Documents (VIIthXVIIIth Century): Bulletin of the Seismological Society of America, Vol. 70, p. 2185-2201. 
Proceedings of the 12 $^{\text {th }}$ ICCAE-12 Conference, 3-5 April, 2018

Soloviev, S.L., Solovieva, O.N., Go, C.N., Kim, K.S., and Shchetnikov, N.A., (2000). Tsunamis in the Mediterranean Sea 2000 B.C.-2000 A.D, pp. 237, Kluwer academic, Dordrecht/ Boston/ London ISBN: 07923-6548-8. 